\title{
Color Tissue Doppler Ultrasound Mode
}

National Cancer Institute

\section{Source}

National Cancer Institute. Color Tissue Doppler Ultrasound Mode. NCI Thesaurus. Code C130061.

A method of ultrasound imaging that uses pulsed wave Doppler signals to depict tissue motion direction and velocity in color images that are superimposed over normal, 2D images. 